\title{
Komemoracja postaci metropolity Andrzeja Szeptyckiego w 2015 roku a proces demokratyzacji na Ukrainie po rewolucji godności*
}

\section{Commemoration of the Metropolitan Andrey Sheptytsky in 2015 and the Process of Democratization in Ukraine after the Revolution of Dignity}

\section{Abstract}

As a consequence of the crisis related to the overthrowof the president Yanukovych in Ukraine, anew social reality evolved. The changes are reflected, inter alia, in the reinterpretation of the identity and borders of the political community in Ukraine. The representatives of the Ukrainian elites who took over the power in 2014 actively joined this process. The proof of this fact is, inter alia, an initiative of the nationwidecelebrationof the $150^{\text {th }}$ anniversary of the birth of the Metropolitan Andrey Sheptytsky.

The reinterpretation of the own cultural heritage and the process of formation of the symbolic capital (as understood by P. Bourdieu) related with this heritage became more dinamic after the so-called Revolution of Dignity and in view of the armed conflict in Donbass. It seems that a modernised universal formula of the Ukrainian identity could

* Artykuł powstał w ramach realizacji grantu z NCN 2015/19/B/HS6/01257. 
be based largly on the cultural capital of one of the regions of Ukraine: Galicia. The currect Ukrainian authorities' initiatives targeted at the promotion of the figure of the Metropolitan Andrey Sheptysky seem to indicate it. The analysis of theirprogressand shall enable a better understanding of the meaning and direction of social changes in today's Ukraine.

Keywords: Revolution of Dignity, cultural capital, Metropolitan Andrey Sheptytsky, reinterpretation of identity, democratization

\section{Коммеморация митрополита Андрея Шептицкого В 2015 году и процесс демократизации на Украине после Революции достоинства}

\section{Аннотация}

В результате кризиса, связанного со свержением президента В. Януковича на Украине, возникла новая социальная реальность. Проявлением этих изменений является, в частности, реинтерпретация идентичности и границ политического сообщества на Украине. В этот процесс активно подключились представители украинской элиты, пришедшие к власти в 2014 году. Об этом, в частности, свидетельствует инициатива празднования на государственном уровне 150-летия со дня рождения митрополита Андрея Шептицкого.

После так называемой Революции достоинства и перед лицом военного конфликта на Донбассе, реинтерпретация собственного культурного наследия и процесс формирования связанного с ним символического капитала (в понимании П. Бурдье) приобрели новую динамику. Как кажется, модернизированная универсальная формула украинской идентичности будет в значительной степени базироваться на культурном капитале одного из регионов Украины - Галиции. Инициативы нынешних украинских властей, направленные на популяризаци личности митрополита Андрея Шептицкого, похоже, являются тому свидетельством. Анализ этих действий должен позволить лучше осмыслить направление социальных изменений в современной Украине.

Ключевые слова: Революция достоинства, культурный капитал, митрополит Андрей Шептицкий, реинтерпретация идентичности, демократизация

\section{Wstęp}

Tożsamość i granice wspólnoty politycznej są wyznaczane przez wzorce 1 kulturowe, pamięć historyczną oraz władzę (Wnuk-Lipiński, 2004, s. 231, 234). W ciągu ostatnich lat można było zaobserwować na Ukrainie proces 
dynamicznych zmian tak rozumianej tożsamości. W konsekwencji kryzysu związanego z obaleniem prezydenta Wiktora Janukowycza na Ukrainie ukształtowała się nowa rzeczywistość społeczna. W ten proces aktywnie włączyli się przedstawiciele ukraińskich elit, którzy w 2014 roku przejęli władzę nad państwem. Świadczy o tym między innymi inicjatywa ogólnoukraińskich obchodów państwowych 150. rocznicy urodzin metropolity Andrzeja Szeptyckiego.

Celem badawczym artykułu jest odpowiedź na pytanie czy w związku ze zmianami społeczno-politycznymi po rewolucji godności mechanizmy działania państwa ukraińskiego przejawiają tendencje do demokratyzacji na przykładzie komemoracji metropolity Andrzeja Szeptyckiego w 2015 roku. Ponadto, celem jest także próba analizy sposobu funkcjonowania państwa ukraińskiego po 2014 roku oraz próba opisu nowej rzeczywistości społeczno-politycznej na Ukrainie, którą ukształtowały wydarzenia tj. rewolucja godności, aneksja Krymu czy konflikt na wschodzie Ukrainy.

Podstawowa hipoteza pracy zakłada, że ustanowienie ogólnopaństwowych obchodów 150. urodzin metropolity Andrzeja Szeptyckiego jest częścią zmian wewnętrznych, które nastąpiły w przestrzeni społeczno-politycznej na Ukrainie po rewolucji godności i zdają się one świadczyć o stopniowej demokratyzacji sposobów działania państwa ukraińskiego. Drugim założeniem artykułu jest stwierdzenie, iż w konsekwencji zmian społeczno-politycznych po rewolucji godności działania państwa ukraińskiego skoncentrowane są wokół reinterpretacji ukraińskiej tożsamości i granic wspólnoty politycznej, w tym kreowania polityki historycznej i eksponowania ukraińskich elementów kapitału kulturowego, a komemoracja postaci metropolity A. Szeptyckiego w 2015 roku jest częścią tego procesu.

W celu zrealizowania zadań badawczych, należy omówić nie tylko szerszy kontekst społeczno-polityczny, ale przede wszystkim dokonać analizy ogólnopaństwowych obchodów 150. urodzin hierarchy. W tym celu zastosowano metodę badawczą studium przypadku komemoracji postaci metropolity A. Szeptyckiego w 2015 roku w kontekście procesu demokratyzacji na Ukrainie po rewolucji godności. Zbadano dokumenty normatywne dotyczące organizacji uroczystości, tj. rozporządzenia rządowe i samorządowe oraz źródła zastane: materiały prasowe i relacje z przebiegu poszczególnych wydarzeń. Została zastosowana teoria kapitałów Pierre’a Bourdieu oraz podejście 
historyczne, dzięki któremu przybliżony został kontekst nowej rzeczywistości społecznej na Ukrainie po 2014 roku oraz sylwetka metropolity i jej znaczenie jako galicyjskiego kapitału kulturowego.

Analiza komemoracji metropolity Andrzeja Szeptyckiego powinna pozwolić lepiej zrozumieć sens i kierunek przemian społecznych na współczesnej Ukrainie. Ze względu na ograniczenia związane z objętością artykułu, w niniejszej pracy zostały zaprezentowane wyselekcjonowane treści dotyczące problemu badawczego, jego analizy i wyników badań. Artykuł może stanowić punkt wyjścia do dalszych prac badawczych.

Zagadnienie ukraińskiej rzeczywistości społecznej i politycznej przyciągało uwagę wielu badaczy w Polsce i na świecie. Problematyka ukraińska była analizowana $\mathrm{z}$ wielu perspektyw $\mathrm{m}$.in. nauk politycznych, socjologii, historii oraz perspektywy kulturoznawczej. Znalazło to odzwierciedlenie w następującej literaturze przedmiotu, która pośrednio lub bezpośrednio odnosi się do podjętego tematu, m.in.: Politics and Society in Ukraine (D'Anieri, Kravchuk, Kuzio, 1999), Ukraina jako obszar wpływów międzynarodowych po zimnej wojnie (Kapuśniak, 2008), Historia Ukrainy: 1772-1999. Narodziny nowoczesnego narodu (Hrycak, 2000), Ukraina. Czas przemian po rewolucji godności (Furier, red., 2017), czasopismo Politeja Studia ukraińskie (2015), artykuły: National Identity in Ukraine: Impact of Euromaidan and the War (Kulyk, 2016), Revolution without regime change: The evidence from the post-Euromaidan Ukraine (Matsiyevsky, 2018) oraz Gerrymandering Ukraine? Electoral Consequences of Occupation (D'Anieri, 2019).

\section{Demokratyzacja w państwach postkomunistycznych}

W społeczeństwach postkomunistycznych przebieg procesu kształtowania pamięci zbiorowej może wskazywać na charakter szerszych procesów społeczno-politycznych, zachodzących w danej zbiorowości, w tym demokratyzacji.

Standardowe rozumienie pojęcia demokratyzacji może obejmować trzy czynniki: koniec rządów autorytarnych, zaprowadzenie systemu demokratycznego oraz jego konsolidację (Skorupka, 2016, s. 210).

Według Samuela Huntingtona demokratyzacja państw dokonywała się w trzech falach, które przeplatały się z falami odwrotu od niej. Przedstawionemu 
problemowi badawczemu, jakim jest demokratyzacja państwa ukraińskiego, odpowiada trzecia fala demokratyzacji. W państwach komunistycznych proces ten zachodził poprzez zastępowanie systemów autorytarnych systemami demokratycznymi i dotyczył przechodzenia do systemu wielopartyjnego na przełomie lat 80. i 90. Państwa, takie jak Ukraina, które trzecia fala demokratyzacji objęła najpóźniej, bo po 1990 roku, nie miały wcześniej styczności z systemem demokratycznym (Huntington, 2009, s. 23-33).

Adam Przeworski, badając przejścia od rządów autorytarnych do demokracji, stwierdził, że pewne uwarunkowania gospodarcze, społeczne czy polityczne nie determinują przemian ustrojowych w znaczącym stopniu, lecz że stanowią one pewne ograniczenia, odnośnie tego co jest możliwe $\mathrm{w}$ danym okresie historycznym. Ponadto utrata legitymacji przez władzę autorytarną nie jest wystarczającym czynnikiem załamania się reżimu i rozpoczęcia demokratyzacji państwa. Zmiana ustrojowa z rządów autorytarnych na demokrację wiąże się z konfliktami, które mogą rozwiązać kompromisy instytucjonalne. W takiej sytuacji zagrożeniem dla demokratyzacji może być ograniczenie się do formalnych ustaleń politycznych, bez następstw społeczno-ekonomicznych (Przeworski, 1991, s. 47-63).

Od momentu upadku reżimów komunistycznych w 1989 roku pojęcie demokratyzacji ma szczególnie istotne znaczenie dla przemian społeczno-politycznych w Europie Środkowo-Wschodniej. Dychotomiczne pojęcia demokracji i niedemokracji wydają się niewystarczające do opisu dynamiki przemian ustrojowych. Demokratyzacja rozumiana jako wdrażanie procesów demokracji i proces przeistaczania się w demokrację, zdaje się wypełniać tę lukę (Holzer, 2015, s. 43).

W kontekście Ukrainy aktualne wydaje się być zagadnienie czy w mechanizmach - przede wszystkim tych wdrażanych przez instytucje państwowe można zaobserwować pewne tendencje związane z procesem demokratyzacji. By móc odpowiedzieć na to pytanie, kluczowa wydaje się być kwestia na ile owe mechanizmy opierają się na narzucaniu jednostronnej wizji, a w jakim stopniu są adekwatne do pluralistycznego modelu życia społecznego. Pewnych wskazówek w tej kwestii dostarcza sposób, w jaki w danym przypadku jest kształtowana polityka historyczna (Nowak, 2011, s. 110).

Ponadto, by analizować proces demokratyzacji państwa ukraińskiego, należy uwzględnić jego postsowiecką specyfikę oraz funkcjonowanie 
w oparciu o system oligarchiczny. Panują w nim własne zasady, które polegają na działaniach nieformalnej i ograniczonej grupy lub grup posiadających władzę, których reprezentanci - oligarchowie zbudowali sieć powiązań i zależności. W ten sposób dbają oni o interesy różnych środowisk, ugrupowań czy polityków i sprawują nad nimi patronat niejako jak nad swoimi klientami (Mączak, 2003, s. 11-14, 38-44; Konończuk, 2016, s. 8-9). Współczesne ukraińskie elity rządzące zostały ukształtowane w środowisku oligarchicznym, które realizowało własne interesy, a nie obywateli. W 2014 roku doszły do władzy dzięki buntowi społeczeństwa podczas rewolucji godności oraz zmianie dotychczasowego rządu, prezydenta i większości parlamentarnej.

\section{Wspólnota polityczna (społeczeństwo polityczne) i jej tożsamość}

Pojęcie „wspólnoty politycznej” można rozumieć w różny sposób. Z punktu widzenia podjętego tematu szczególnie perspektywiczne wydaje się ujęcie Prossa, według którego oznacza ona wspólnie rozumiany system przekonań, reguł postępowania i określony wzorzec zachowań (Atkinson i Coleman, 2009, s. 99). Znaczenie zagadnienia wspólnoty politycznej dopełnia sposób rozumienia społeczeństwa politycznego, któremu „system wiar spajających”, zapewnia przetrwanie i funkcjonowanie jako oddzielnej całości na przestrzeni dziejów. Można uznać, że do obecnego „systemu wiar spajających” na Ukrainie zaliczają się wzorce kulturowe, pamięć historyczna oraz władza. Takie wspólnoty powstają w wyniku procesu - artykulacji społeczeństwa, w którym ogół przekształca się w działającą wspólnotę (Voegelin, 1992, s. 40-41, 44-45). Wydaje się, że aktualnie mamy do czynienia z takim procesem na Ukrainie.

System wiar spajających kształtuje i umacnia społeczeństwo polityczne w oparciu o odpowiedni kapitał kulturowy. To ten rodzaj kapitału, którego ukształtowanie się jest najdłuższe i najtrudniejsze, podobnie jak i jego odebranie. Według Bourdieu inwestycje w kapitał kulturowy mają zazwyczaj charakter pragmatyczny, choć najczęściej ukryty i kreowany jako źródło wyższych wartości (Matuchniak-Krasuska, 2010, s. 37-39; Zarycki, 2009, s. 13-19). 
Na przykładzie analizowanego przypadku oznacza to, że władze ukraińskie „zainwestowały” w kapitał kulturowy związany z metropolitą Szeptyckim poprzez fakt, że ustanowiły obchody 150. jego urodzin na szczeblu państwowym. Z jednej strony celem tej „inwestycji” było wyeksponowanie galicyjskich, a poprzez to ukraińskich elementów kapitału kulturowego, kreowanego w sferze publicznej jako „źródło wyższych wartości”. Z drugiej strony, pragmatycznym celem ,inwestycji” władz ukraińskich w ten kapitał kulturowy było uzyskanie legitymizacji społecznej.

Kapitał kulturowy wraz z kapitałem społecznym i ekonomicznym podlegają konwersji na kapitał symboliczny, a on wymaga społecznego uznania, zaufania oraz przyzwolenia. Kapitał symboliczny może przekształcić się w dominację symboliczną, tzw. przemoc symboliczną i uprawomocnić legalność panowania (Matuchniak-Krasuska, 2010, s. 37-39; Zarycki, 2009, s. 13-19). W tym przypadku narzędziem dominacji symbolicznej byłoby wykorzystanie ukraińskiego kapitału kulturowego - osoby i działalności metropolity Andrzeja Szeptyckiego i Ukraińskiej Cerkwi Greckokatolickiej, a celem dominacji symbolicznej byłoby uzyskanie legitymizacji i utrzymanie władzy.

Jednocześnie, w związku z prowadzeniem na wschodzie Ukrainy wojny hybrydowej - nie tylko militarnej, ale i informacyjnej, ukraińscy rządzący stanęli przed problemem oparcia się przemocy symbolicznej ze strony Rosji.

\section{Życiorys Szeptyckiego z uwzględnieniem znaczenia kapitału galicyjskiego}

Poprzez ustanowienie obchodów 150. urodzin metropolity, na terenie całej Ukrainy został uruchomiony mechanizm transferu kapitału kulturowego swoistego dla Galicji na pozostałe regiony.

Specyfika tego kapitału wynika $\mathrm{z}$ faktu, iż Galicja przez stulecia należała do innych struktur państwowych niż reszta ziem ukraińskich i dopiero po jej włączeniu do ZSRS w 1939 roku znalazły się one w granicach jednego państwa. W konsekwencji dochodziło do kształtowania się społeczeństw i wzorców kulturowych w różnych warunkach oraz w odmienny sposób. Odwołanie się przez ukraińskie władze akurat do galicyjskiego kapitału kulturowego podkreśla związki Galicji, a przez nią całej Ukrainy, z Europą 
Zachodnią, gdyż geograficznie, kulturowo i politycznie Galicja podlegała wpływom zachodnioeuropejskim przez stulecia. Region ten był częścią Monarchii Austro-Węgierskiej, a także Rzeczpospolitej, co sprawiało, że stykano się z zachodnimi wzorcami kulturowymi (Hrycak, 2000, s. 25-27, 29, 188).

Andrzej Szeptycki, którego postać i działalność postanowiły uroczyście upamiętnić władze ukraińskie, był duchownym greckokatolickim, biskupem stanisławowskim, a w latach 1900-1944 arcybiskupem metropolitą lwowskim i halickim, najwyższym zwierzchnikiem Cerkwi greckokatolickiej. Szeptycki jest postrzegany jako jedna z kluczowych postaci w Galicji (Kuszka, 2011, s. $18-20,22,24)^{1}$.

Andrzej Szeptycki żył w latach 1865-1944 i pochodził z polskiej arystokratycznej rodziny. Przodkowie ze strony ojca hrabiego Jana Kantego Szeptyckiego byli spolonizowaną szlachtą ruską, u której obecne były tradycje kapłańskie obrządku wschodniego. Natomiast matka metropolity, Zofia Szeptycka, była hrabianką i córką polskiego komediopisarza Aleksandra Fredry. Przyszły hierarcha został wychowany w rodzinie rzymskokatolickiej, ale zmienił obrządek na greckokatolicki i stał się duchowym przywódcą Ukraińców żyjących w Galicji (Kuszka, 2011, s. 17, 20, 24; Zięba, 1994, s. 11-13).

Metropolita wspierał ukraińskie dążenia niepodległościowe i powstanie Zachodnioukraińskiej Republiki Ludowej, co miało miejsce 13 listopada 1918 roku na terenie Galicji Wschodniej. Tym samym udzielił swego poparcia stronie ukraińskiej podczas trwania konfliktu między Polakami a Ukraińcami (Koko, 1995, s. 55-56; Kubasik, 1999, s. 87). Arcybiskup działał na rzecz ekumenizmu, był także działaczem społecznym na polu kultury, gospodarki, oświaty czy pomocy najuboższym (Kuszka, 2011, s. 19, 24). Podczas Holokaustu oraz pogromów przewodniczył organizowaniu i koordynowaniu podziemnej strukturze ratującej lwowskich Żydów (Бусraнr, 2009, s. 31-32).

1 Patrz więcej: Z. Szeptycka z Fredrów, B. Zakrzewski (oprac.).(1993). Mój syn metropolita Szeptycki. Młodość i powołanie ojca Romana Andrzeja Szeptyckiego zakonu św. Bazylego Wielkiego. Wrocław: Towarzystwo Przyjaciół Polonistyki Wrocławskiej; M.H. Szeptycka, M. Skórka, OSMB (red.). (2000). Metropolita A. Szeptycki. Pisma wybrane. Kraków: Znak; A.A. Zięba, (red.). (1994). Metropolita Andrzej Szeptycki. Studia i materiały. Kraków: Polska Akademia Umiejętności; A. Kubasik (1999). Arcybiskupa Andrzeja Szeptyckiego wizja ukraińskiego narodu, państwa i cerkwi. Lwów-Kraków: Wydawnictwo Bł. Jakuba Strzemię Archidiecezji Lwowskiej Ob. Łac. 
Jednocześnie hierarcha wzbudzał kontrowersje związane m.in. z tym, że przywitał Niemców w 1941 roku (Бусганг, 2009, s. 27) czy wysyłał greckokatolickich duchownych do jednostek SS Galizien jako kapelanów (Motyka, 2011, s. 195). Kwestia oceny działalności arcybiskupa Szeptyckiego, zwłaszcza w latach 1939-1944, jest złożona i wymaga uwzględnienia okoliczności wojennych, rozróżnienia publicznego i niepublicznego charakteru działań hierarchy oraz przeanalizowania różnych kierunków działań metropolity.

Równie problematycznym zagadnieniem jest stosunek arcybiskupa Szeptyckiego do ukraińskiego ruchu narodowego oraz działaczy OUN-M i OUN-B. Duchowny wspierał ukraiński ruch narodowy i uchodzi do tej pory za jego duchowego przywódcę (Motyka, 2011, s. 179). Lobbował za uzyskaniem niepodległości przez Ukrainę, co czynił w okresie międzywojennym, jeżdżąc po świecie i zabiegając o poparcie wpływowych działaczy dla sprawy ukraińskiej w Galicji (Kuszka, 2011, s. 18-19). Jednakże zawsze przedstawiał swoje stanowisko z perspektywy etyki chrześcijańskiej np. w listach „O miłosierdziu”; „Nie zabijaj” (Motyka, 2011, s. 179). Warto również podkreślić, że metropolita stworzył koncepcję chrześcijańskiego patriotyzmu, która jest sprzeczna $z$ ideologią integralnego nacjonalizmu uznawaną przez OUN-B i UPA (Wawrzonek, 2010, s. 199-206).

W Związku Sowieckim postać metropolity Andrzeja Szeptyckiego kreowana była jako wroga wobec reszty społeczeństwa i jego interesów. Hierarcha przedstawiany był jako kolaborant z Niemcami, uosabiając negatywne cechy. Sposób postrzegania arcybiskupa ówcześnie, jak i obecnie może wynikać ze zróżnicowania regionalnego Ukrainy i propagandy, zwłaszcza komunistycznej, rozpowszechnianej po jego śmierci w 1944 roku do lat 90. (Zięba, 1998, s. 287-310).

W związku z trwającym od 2014 roku konfliktem militarnym na wschodzie Ukrainy, odwoływanie się do kapitału kulturowego Galicji można interpretować jako przejaw poszukiwania „systemu wiar spajających” przez Ukraińców, co może pomóc zapewnić im poczucie odrębności względem Rosji, pozwolić wyeksponować przynależność tego regionu, a także Ukrainy do zachodnioeuropejskiego kręgu kulturowego i cywilizacyjnego. Galicja wraz z jej dziedzictwem - Cerkwią greckokatolicką i postacią metropolity Andrzeja Szeptyckiego - mogą być ukraińskimi symbolami czerpania z zachodnich wzorców przy dążeniu do zachowania własnych wartości. Można 
przypuszczać, że dlatego komemoracja A. Szeptyckiego stała się jednym z narzędzi mających legitymizować elity polityczne, które przejęły władzę na Ukrainie po obaleniu W. Janukowycza.

\section{Nowa dynamika procesu kształtowania „systemu wiar spajających” na Ukrainie}

Wydarzeniem, które zdecydowanie wskazało na kształtowanie się nowego „systemu wiar spajających” na Ukrainie, był wybuch masowych protestów antyrządowych 21 listopada 2013 roku w Kijowie. Przerodziły się one w rewolucję przeciwko rządom prezydenta Wiktora Janukowycza, określoną później tzw. rewolucją godności. Wiece protestacyjne odbywały się również w innych częściach kraju. Ostatecznym bodźcem, po którym Ukraińcy rozpoczęli manifestacje, było niepodpisanie przez ich prezydenta umowy stowarzyszeniowej z Unią Europejską. Kulminacyjnym momentem Euromajdanu stało się otworzenie ognia do protestujących podczas ulicznych walk w dniach od 18 do 20 lutego 2014 roku, na skutek czego śmierć poniosło 108 osób (Національний Меморіальний Комплекс Героїв Небесної Сотні. Музей Революції Гідності, b.d.).

Odpowiedzialnością za decyzje o zastosowaniu przemocy wobec ludności cywilnej obarcza się Wiktora Janukowycza, ówczesnego prezydenta Ukrainy. Pod naciskiem zagranicznej i ukraińskiej opinii publicznej oraz unijnych dyplomatów Janukowycz ogłosił projekt uchwały o przeprowadzeniu przedterminowych wyborów prezydenckich, a sam opuścił Ukrainę. Decyzję podtrzymała Rada Najwyższa Ukrainy (Верховна Рада України. 2014, 20 lutego; 2014, 22 lutego). W związku z opuszczeniem Partii Regionów przez część jej deputowanych, uformowała się nowa większość parlamentarna, od której protestujący na Euromajdanie domagali się wprowadzenia szybkich zmian politycznych (Kłymonczuk, 2015, s. 100).

Oprócz rewolucji godności, wydarzeniami, które wpłynęły na proces kształtowania się nowej rzeczywistości społeczno-politycznej, były aneksja Krymu przez Rosję oraz wybuch konfliktu zbrojnego na wschodzie Ukrainy (Pawlak, 2017, s. 277-281). Aneksja półwyspu została negatywnie oceniona jako naruszenie norm prawa międzynarodowego m.in. przez Kongres Władz Regionalnych i Lokalnych Europy - jeden z organów Rady Europy. 
W oświadczeniu potępił on aneksję, nie uznał referendum z 16 marca i udzielił poparcia nowym ukraińskim władzom (Ministry of Foreign Affairs of Ukraine, 2014, 25 marca).

Natomiast w połowie kwietnia 2014 roku w obwodzie donieckim oraz ługańskim na wschodzie Ukrainy miały miejsce wystąpienia prorosyjskich separatystów, którzy okazali się być wspierani militarnie przez Rosję. Proklamowali oni Doniecką Republikę Ludową oraz Ługańską Republikę Ludową. Ukraińskie władze zareagowały na te antypaństwowe działania ogłoszeniem rozpoczęcia Operacji Antyterrorystycznej z udziałem Sił Zbrojnych (Konończuk, 2014, 8 maja; Żochowski, Sadowski i Menkiszak, 2014, 3 września). Konfrontacja ta stopniowo przeradzała się w wojenny konflikt na dużą skalę i stała się częścią wojny hybrydowej pomiędzy Ukrainą a Rosją (Pawlak, 2017, s. 278-281, 286).

Kolejnym elementem kształtującym nowy „system wiar spajających” oraz przejawem reinterpretacji granic wspólnoty politycznej na Ukrainie stały się działania ukraińskich władz, które miały na celu kształtowanie nowej polityki historycznej. W 2015 roku Rada Najwyższa Ukrainy uchwaliła cztery ustawy o polityce pamięci. Były to: 1) Ustawa o dostępie do archiwów organów represyjnych komunistycznego reżimu totalitarnego z lat 1917-1991; 2) Ustawa o uwiecznieniu zwycięstwa nad nazizmem w II wojnie światowej 1939-1945; 3) Ustawa o statusie prawnym i uczczeniu pamięci uczestników walk o niepodegłość Ukrainy w XX wieku oraz 4) Ustawa o potępieniu komunistycznego i narodowosocjalistycznego (nazistowskiego) reżimów totalitarnych i zakaz propagowania ich symboliki. Szkice ustaw zostały przygotowane przez Ukraiński Instytut Pamięci Narodowej. Wprowadzenie w życie ustaw miało na celu m.in. dekomunizację przestrzeni publicznej na dużą skalę, w tym zmianę wszystkich nazw miejscowych związanych z komunizmem, uznanie komunistycznego (1917-1991) i nazistowskiego reżimów totalitarnych za systemy przestępcze oraz wprowadzenie delegalizacji sowieckiej i nazistowskiej symboliki, a także umożliwienie dostępu do archiwów struktur sowieckich. (Rybak, 2015, s. 5-11; Про увічнення..., 2015; Про доступ..., 2015; Про засудження..., 2015; Про правовий..., 2015).

W ten kontekst wpisuje się także kolejny element kształtowania nowej rzeczywistości społecznej po 2014 roku, czyli odwołanie się ukraińskich władz do rodzimego galicyjskiego kapitału kulturowego poprzez ustanowienie 
ogólnopaństwowych obchodów z okazji 150. urodzin metropolity Ukraińskiej Cerkwi Greckokatolickiej Andrzeja Szeptyckiego.

\section{Komemoracja. Przykłady działań na poziomie ogólnopaństwowym}

Rada Najwyższa Ukrainy, przyjmując projekt Uchwały o obchodach 150. urodzin metropolity Ukraińskiej Cerkwi Greckokatolickiej Andrzeja Szeptyckiego, ustanowiła uroczyste obchody jubileuszu arcybiskupa przez cały 2015 rok na szczeblu państwowym (Верховна Рада України, 2014, 17 czerwca). W rozporządzeniu Kancelarii Szefa Rady Ministrów Arsenija Jaceniuka z dnia 29 kwietnia 2015 roku znalazł się Plan przygotowań i obchodów w (2015 roku) 150-lecia urodzin metropolity (Ukraińskiej Cerkwi Greckokatolickiej Andrzeja Szeptyckiego). Obejmował on m.in. przeprowadzenie państwowych uroczystości, wystaw tematycznych, wydarzeń książkowych, przeglądów literatury czy sympozjów, związanych z życiem i działalnością metropolity. W skład komitetu organizacyjnego, odpowiedzialnego za przygotowania i przebieg wydarzeń związanych z obchodami, weszły osoby piastujące wysokie stanowiska w dziedzinie polityki, nauki i kultury, m.in. wicepremier Ukrainy i minister kultury Wiaczesław Kyrylenko oraz przedstawiciele obwodowych administracji państwowych (Кабінет Міністрів України, 2015, 29 kwietnia; Прес-Служба Міністерства Культури, (2015, 5 maja).

Najbardziej uroczyste obchody jubileuszu 150. urodzin metropolity Szeptyckiego miały miejsce we Lwowie, zwłaszcza 29 lipca - w dniu urodzin greckokatolickiego hierarchy - na tereniea archikatedry św. Jura, gdzie w krypcie spoczywa ciało arcybiskupa. Oprócz liturgii głównym punktem upamiętnienia hierarchy było wzniesienie i odsłonięcie poświęconego mu pomnika na placu przed świątynią. Z okazji uroczystości na placu pod świątynią zgromadziło się kilkadziesiąt tysięcy wiernych. Na ceremonię przybył prezydent Ukrainy Petro Poroszenko, hierarchowie Kościołów innych wyznań oraz władze obwodu lwowskiego (Czawaga, 2015, 3 sierpnia).

Natomiast w Kijowie w rocznicę śmierci hierarchy, 1 listopada 2015 roku miały miejsce obchody państwowo-religijne. $\mathrm{W}$ ich ramach odbyła się uroczysta liturgia i akademia, podczas której słowo powitalne wygłosił rabin Kijowa i Ukrainy Jacob Dow Blaich, patriarcha Ukraińskiej Cerkwi 
Prawosławnej Kijowskiego Patriarchatu - Filaret, metropolita Ukraińskiej Cerkwi Greckokatolickiej Światosław Szewczuk oraz premier Arsenij Jaceniuk (2015, 3 listopada).

Od 30 października do 1 listopada 2015 roku we Lwowie miało miejsce Międzynarodowe Sympozjum związane ze 150-leciem urodzin metropolity. W jego ramach odbyło się wiele wydarzeń, jak np. konferencja poświęcona działalności metropolity Szeptyckiego czy obrady plenarne z udziałem przedstawicieli różnych wspólnot wyznaniowych: greckokatolickiej, prawosławnych, muzułmańskiej, żydowskiej (Національний університет „Львівська Політехніка", 2015, 4 listopada).

Oprócz opisanych wydarzeń podejmowano wiele innych działań na rzecz upamiętniania metropolity. W organizacji obchodów uczestniczyły środowiska polityczne najwyższego szczebla, lokalne samorządy i administracja, zwierzchnicy Ukraińskiej Cerkwi Greckokatolickiej, a także duchowni przedstawiciele innych wspólnot religijnych, ludzie nauki, kultury i sztuki, społeczność ukraińska. Także różnorodność zaangażowanych instytucji wskazuje na dużą skalę przedsięwzięcia związanego z komemoracją postaci i działalności metropolity Szeptyckiego. Dzięki dokonanej poniżej analizie obchodów w obwodzie kirowohradzkim, będzie można zaobserwować czy rzeczywiście tak było na poziomie lokalnym.

\section{Przykłady komemoracji na poziomie lokalnym - obwód kirowohradzki}

Po analizie porównawczej planu administracji obwodu kirowohradzkiego z planem rządowym, można zauważyć duże podobieństwo ich formy oraz treści, co wynika $z$ wzorowania się administracji obwodowej na planie rządowym. Nie powinno to dziwić czy niepokoić, gdyż lokalne obchody miały być przeprowadzone w oparciu o ten plan. Jednak warto zauważyć, iż rozporządzenie lokalnej administracji nie zawiera własnych propozycji działań w związku z obchodami urodzin arcybiskupa (Кабінет Міністрів України, 2015, 29 kwietnia; Кузьменко, 2015, 10 lipca).

$\mathrm{Na}$ uwage zasługuje ostatni podpunkt planu jubileuszu urodzin duchownego, który stanowi o sprzyjaniu władz samorządowych kwestii zwiedzania przez „zorganizowane grupy uczniów miejsc związanych z życiem 
i działalnością metropolity Andrzeja Szeptyckiego" (Кузьменко, 2015, 10 lipca). Nie jest jasne, jakie miejsca i jakie trasy turystyczno-wycieczkowe dzieci i młodzież miałyby zwiedzać. Zwłaszcza, że co do zasady działalność i zadania wymienionego Departamentu Kultury Turystyki i Dziedzictwa Kulturowego są ograniczone do obszaru obwodu kirowohradskiego (Управління освіти, науки, молоді та спорту Кіровоградської облдержадміністрації, b.d.). Tymczasem arcybiskup Szeptycki nigdy nie był w Kirowohradzie i obwodzie kirowohradzkim i nie ma żadnych ogólnie znanych dokumentów, które by mogły to potwierdzić. Jeśli zaś lokalne władze rzeczywiście zamierzały zorganizować wycieczki do miejsc związanych z Andrzejem Szeptyckim, to ze względu na koszty jest mało prawdopodobne, by doszło do realizacji tych zadań - w każdym razie nie udało się znaleźć danych, które by o tym świadczyły. W związku z tym nasuwa się wniosek, że lokalne władze obwodu kirowohradzkiego nie przywiązywały dużej uwagi do rzeczywistych możliwości zrealizowania własnych propozycji zawartych w planie obchodów upamiętnienia metropolity. Sytuacja ta mogłaby wskazywać na rutynowe, bezrefleksyjne działania lokalnej administracji. Tak realizowana polityka pamięci może prowadzić do jej jeszcze większej instrumentalizacji przez władzę.

Przewodniczący administracji obwodowej Serhii Kuzmenko zlecił wykonanie rządowego rozporządzenia, dotyczącego komemoracji metropolity Szeptyckiego, organom niższego szczebla. W rozporządzeniu oraz planie obchodów Znamianeckiej Rejonowej Administracji Państwowej jej przewodniczący Jurij Huhlenko powielił odgórnie wyznaczone działania przez rządowe i obwodowe władze (Гугленко, 2015, 23 lipca).

W ramach realizacji tegoż rozporządzenia o organizacji obchodów w jednym z liceów w mieście Znamianka odbyło się wydarzenie poświęcone komemoracji arcybiskupa, przygotowane dla tamtejszych uczniów i pedagogów pt. „Życie i działalność metropolity Andrzeja Szeptyckiego”. Spotkanie poprowadzili przedstawiciele Ukraińskiej Cerkwi Greckokatolickiej. Opowiadali oni o życiu i działalności metropolity, oprócz tego rozdano pamiątkową literaturę, a także wyświetlono film dokumentalny (Християнський Портал Кipioc, 2015, 9 grudnia). Udział w wydarzeniu pozwolił zapoznać się z sylwetką metropolity, co było w dużej mierze zasługą greckokatolickiego duchownego i siostry zakonnej, którzy prowadzili owe spotkanie. Natomiast 
władze rejonowe i obwodowe nie miały własnego pomysłu i nie zaangażowały się w realizację rządowego rozporządzenia ponad to, co było konieczne.

Powyżej opisane działania wskazują na to, że organizowanie uroczystości upamiętniającej Andrzeja Szeptyckiego było związane z kreowaniem polityki historycznej na zasadzie administracyjnych dyrektyw. Zamiast dialogu pomiędzy poszczególnymi instytucjami i wspólnych ustaleń rząd zastosował paradygmat nakazowo-rozdzielczy, a część władz obwodowych powieliła go i w swoich działaniach nie wyszła poza odgórny schemat oprócz tego, co musi wykonać ${ }^{2}$. Wygląda na to, że problem polegał na braku innych pomysłów niż te narzucone. Teoretycznie była dowolność w organizacji obchodów, ale $\mathrm{w}$ praktyce $\mathrm{w}$ wielu przypadkach realizacja tych zadań przejawiała się brakiem inwencji i zaangażowania lokalnych administracji. Prawdopodobnie taka bierność wynika z postsowieckiego sposobu myślenia oraz sprawowania i rozumienia władzy, który polega na wykonywaniu narzuconych dekretów oraz odgórnym kreowaniu rzeczywistości społecznej. Poprzez politykę historyczną ukraińskie władze starały się wpłynąć na społeczeństwo ukraińskie przy wykorzystaniu kapitału symbolicznego związanego z metropolitą i przy użyciu przemocy symbolicznej związanej z tym kapitałem.

Ze względu na ograniczenia związane $z$ objętością artykułu, powyżej zaprezentowano organizację i przebieg obchodów komemoracji metropolity Szeptyckiego na poziomie lokalnym na przykładzie obwodu kirowohradzkiego. Analiza rozporządzeń i organizacji obchodów w innych obwodach Ukrainy wskazuje, iż mogą wystąpić pewne różnice regionalne co do charakteru, przebiegu oraz zaangażowania lokalnych władz i społeczności.

W Galicji na zachodzie Ukrainy, gdzie metropolita żył, działał oraz znajduje się najwięcej grekokatolików w kraju, odbywało się wiele wydarzeń i inicjatyw w ramach obchodów jubileuszu, w których licznie uczestniczyła lokalna społeczność. Przeanalizowane dotychczas rozporządzenia oraz materiały wskazują, iż w ramach organizacji obchodów urodzin arcybiskupa poza Galicją i Kijowem, podejmowano nieco mniej inicjatyw, na mniejszą skalę i w mniej uroczysty sposób.

2 Potwierdza to analiza obchodów w innych obwodach Ukrainy. Ze względu na ograniczoną ilość znaków przywołano tylko obwód kirowohradzki. 


\section{Wnioski}

\section{Czy komemoracja sprzyjała demokratyzacji?}

Zmiany wewnętrzne, które nastąpiły w przestrzeni społeczno-politycznej na Ukrainie po obaleniu prezydenta Wiktora Janukowycza i utworzeniu nowego rządu, zdają się świadczyć o stopniowej demokratyzacji mechanizmów państwa ukraińskiego. Próba reinterpretacji własnego dziedzictwa kulturowego, w tym ustanowienie ogólnopaństwowych obchodów 150-lecia urodzin arcybiskupa Andrzeja Szeptyckiego również są częścią tego procesu. Wyeksponowany podczas komemoracji kapitał kulturowy i symboliczny związany z metropolitą i Cerkwią greckokatolicką uwypukla odrębność kulturową Ukrainy od Rosji i może być ciekawą alternatywą dla poszukującego swej tożsamości społeczeństwa ukraińskiego.

Skądinąd, w kontekście demokratyzacji pamięci, wizja postaci metropolity kreowana podczas obchodów była prezentowana w dosyć jednoznaczny sposób. Hierarchę Szeptyckiego przedstawiano jako wybitnego działacza religijnego i społecznego, nie poruszając pewnych polemicznych tematów związanych z jego postacią.

Jeśli zaś sięgnie się do historii Ukrainy i weźmie się pod uwagę kontekst negatywnego kreowania wizerunku arcybiskupa w czasach sowieckich, to można stwierdzić, że aktualny sposób przedstawiania metropolity Szeptyckiego prezentuje inny, nowy punkt widzenia na jego postać oraz działalność w stosunku do jego negatywnego wizerunku propagowanego do lat 90 . w ZSRS. To wpisuje się w proces eliminacji z „systemu wiar spajających” ukraińskiego społeczeństwa politycznego różnych obciążeń związanych z dziedzictwem sowieckim. Można przyjąć, że to pozytywnie wpłynie na perspektywy dalszej demokratyzacji pamięci oraz na rozwój pluralistycznego modelu życia społecznego na Ukrainie.

\section{Co komemoracja mówi o sposobie działania państwa?}

Obecnie dla ukraińskich elit politycznych trudność w odnalezieniu się w nowej rzeczywistości polega na tym, jak rządzić według znanych sobie dotychczasowych oligarchicznych reguł, a jednocześnie uniknąć kolejnego buntu i uzyskać legitymizację (Konończuk, 2016, s. 15-17). By elity rządzące osiągnęły ten ostatni cel, ludzie powinni być przekonani, że całość 
struktur i działań aparatu władzy posiada cechę przyzwoitości czy dobra moralnego (Dahl, Stinebrickner, 2007, s. 99-100). By tak było wydaje się, że rządzący muszą choć w minimalnym stopniu zabiegać o akceptację ze strony społeczeństwa, brać pod uwage jego postulaty i realizować jego aspiracje. W związku z tym po rewolucji godności i w obliczu konfliktu zbrojnego w Donbasie działania państwa ukraińskiego skoncentrowane są wokół umacniania ukraińskiej tożsamości narodowej poprzez eksponowanie ukraińskich elementów kapitału kulturowego. Wynika to z trwającego procesu reinterpretacji ukraińskiej tożsamości i granic wspólnoty politycznej. Kreowanie polityki historycznej oraz podejmowanie działań z okazji obchodów 150-lecia urodzin metropolity Andrzeja Szeptyckiego są częścią tego procesu. Można je interpretować jako przykład poszukiwania przez obecnie rządzące na Ukrainie elity, nowych sposobów legitymizacji swojej władzy, która jest wciąż podzielona pomiędzy przedstawicieli etosu rewolucji godności oraz tych, którzy usiłują kontynuować dotychczasowy oligarchiczny model funkcjonowania władzy na Ukrainie.

Podczas analizy organizacji i przebiegu obchodów rocznicy urodzin metropolity można było zaobserwować zjawiska, które nie sprzyjają trwającemu procesowi demokratyzacji państwa ukraińskiego. Zauważono stosowanie paradygmatu nakazowo-rozdzielczego, który funkcjonuje pomiędzy rządowymi i lokalnymi strukturami administracji i charakteryzuje ukraiński model rządzenia państwem. Ponadto państwowe i samorządowe władze ukraińskie instrumentalnie wykorzystały kapitał kulturowy jednego z regionów kraju dla własnej legitymizacji. Wymienione działania państwa ukraińskiego oraz zjawisko oligarchii stanowią wciąż aktualną postsowiecką specyfikę współczesnego systemu politycznego na Ukrainie, co wydaje się być niekompatybilne z oczekiwaniami części społeczeństwa ukraińskiego.

\section{MGR OLIWIA KROPORNICKA}

Instytut Nauk o Polityce i Administracji

Akademia Ignatianum w Krakowie

ul. Mikołaja Kopernika 26, 31-501 Kraków

oliwia.kropornicka@gmail.com 


\section{Bibliografia}

W języku angielskim

D’Anieri, P. (2019). Gerrymandering Ukraine? Electoral Consequences of Occupation. East European Politics and Societies, 33(1), 89-108.

D’Anieri, P., Kravchuk, R., Kuzio, T. (1999). Politics and Society in Ukraine. Boulder: Westvew PRESS.

Kulyk, V. (2016). National Identity in Ukraine: Impact of Euromaidan and the War. Europe-Asia Studies, 68(4), 588-608.

Matsiyevsky, Y. (2018). Revolution without regime change: The evidence from the post-Euromaidan Ukraine. Communist and Post-Communist Studies, 51(4), 349-359.

Ministry of Foreign Affairs of Ukraine. (2014, 25 marca). Congress of the Council of Europe condemns the Russian annexation of the Crimea and Sevastopol. Pobrane z: https://mfa.gov.ua/en/news-feeds/foreign-offices-news/20598-kongres-radi-jevropi-zasudzhuje-rosijsyku-aneksiju-krimu-ta-sevastopolyu.

Przeworski, A. (1991). Some problems in the study of the transition to democracy. W: G. O'Donnell, P.C. Schmitter, L. Whitehead (red.). Transitions from Authoritarian Rule: Comparative Perspectives (47-63). Baltimore-London: The Johns Hopkins University Press.

\section{W języku polskim}

Atkinson, M.M., Coleman, W.D. (2009). Sieci polityczne, wspólnoty polityczne oraz problemy związane z rządzeniem. Zarządzanie Publiczne, 4(10), 93-114.

Czawaga, K. (2015, 3 sierpnia). Obchody 150-lecia urodzin metropolity Andrzeja Szeptyckiego. Kurier Galicyjski. Pobrane z: http://kuriergalicyjski.com/spolechenstwo/ religia-kg/4377-obchody-150-lecia-urodzin-metropolity-andrzeja szeptyckiego.

Dahl, R.A., Stinebrickner, B. (2007), Współczesna analiza polityczna, Warszawa: Wydawnictwo Naukowe Scholar.

Dufek, P. (2015). Demokratyzacja demokracji? Podstawowe wyzwania i pytania teorii demokracji. W: J. Holzer, P. Molk (red.). Demokratyzacja a prawa człowieka. Spojrzenie z Europy Środkowej (63-93). Kraków-Brno: Ośrodek Myśli Politycznej i Uniwersytet Masaryka w Brnie.

Furier, A. (red.). (2017). Ukraina. Czas przemian po rewolucji godności. Poznań: Wydawnictwo FNCE.

Holzer, J. (2015). Reżimy niedemokratyczne i demokratyzacja. W: J. Holzer, P. Molk (red.). Demokratyzacja a prawa człowieka. Spojrzenie z Europy Środkowej (43-44). Kraków-Brno: Ośrodek Myśli Politycznej i Uniwersytet Masaryka w Brnie.

Hrycak, J. (2000). Historia Ukrainy 1772-1999. Narodziny nowoczesnego narodu, Lublin: Instytut Europy Środkowo-Wschodniej.

Huntington, S.P. (2009). Trzecia fala demokratyzacji. Warszawa: Wydawnictwo Naukowe PWN.

Kapuśniak, T. (2008). Ukraina jako obszar wpływów międzynarodowych po zimnej wojnie. Warszawa-Lublin: Instytut Europy Środkowo-Wschodniej.

Kłymonczuk, W. (2015). Ukraina w poszukiwaniu wolności - od Rewolucji Godności do wyborów parlamentarnych w 2014 roku. Wschód Europy, 1(2), 93-105. 
Koko, E. (1995). Metropolita Andrzej Szeptycki a państwo polskie w latach 1918-1939. W: T. Stegner (red.). Metropolita Andrzej Szeptycki. Materiały z sesji naukowej (55-69). Gdańsk: Wydawnictwo „STEPAN design”.

Konończuk, W. (2014, 8 maja). Wschodnia Ukraina: ofensywa separatystów w oczekiwaniu na „referendum”. OSW. Pobrane z: https://www.osw.waw.pl/pl/publikacje/ analizy/2014-05-08/wschodnia-ukraina-ofensywa-separatystow-w-oczekiwaniu -na-referendum.

Konończuk, W. (2016). Fundament systemu. Starzy i nowi oligarchowie na Ukrainie. Warszawa: Ośrodek Studiów Wschodnich im. Marka Karpia.

Kubasik, A. (1999). Arcybiskupa Andrzeja Szeptyckiego wizja ukrainskiego narodu, państwa i cerkwi. Lwów-Kraków: Wydawnictwo Bł. Jakuba Strzemię Archidiecezji Lwowskiej Ob. Łac.

Kuszka, P. (2011). Postać sługi Bożego metropolity Andrzeja Szeptyckiego. W: A.R. Szeptycki (red.). Kościól, naród, państwo. Działalność i dziedzictwo Metropolity Andrzeja Szeptyckiego 1865-1944 (17-24). Wrocław-Warszawa: Kolegium Europy Środkowo-Wschodniej im. Jana Nowaka-Jeziorańskiego i Fundacja Rodu Szeptyckich.

Matuchniak-Krasuska, A. (2010). Zarys socjologii sztuki Pierre’a Bourdieu. Warszawa: Oficyna Naukowa.

Mączak, A. (2003). Nierówna przyjaźń: układy klientalne w perspektywie historycznej. Wrocław: Wydawnictwo Uniwersytetu Wrocławskiego.

Motyka, G. (2011). Metropolita Andrzej Szeptycki a konflikt polsko-ukraiński w czasie II wojny światowej. W: A.R. Szeptycki (red.). Kościót, naród, państwo. Działalność i dziedzictwo Metropolity Andrzeja Szeptyckiego 1865-1944 (175-198). Wrocław-Warszawa: Kolegium Europy Środkowo-Wschodniej im. Jana Nowaka-Jeziorańskiego i Fundacja Rodu Szeptyckich.

Nowak, J. (2011). Społeczne reguły pamiętania: antropologia pamięci zbiorowej. Kraków: Nomos.

Pawlak, C. (2017). Konflikt na wschodzie Ukrainy i aneksja Krymu - standardowym przykładem działań hybrydowych. Rocznik Bezpieczeństwa Międzynarodowego, 11(1), 268-287.

Rybak, A. (2015, maja). Ustawy dekomunizacyjne na Ukrainie, Polityka. Komentarze Centrum Europy Wschodniej, UMCS, 8. Pobrane z: https://phavi.umcs. pl/at/attachments/2016/1024/094712-cew-komentarz-nr8-p.pdf.

Skorupka, A. (2016). Demokratyzacja świata według Samuela Huntingtona. Rocznik Filozoficzny Ignatianum, XXII/2, 206-221.

Studia ukraińskie. (2015). W: Politeja, 34(1) (2).

Szeptycka, M.H., Skórka, M. OSMB (red.). (2000). Metropolita A. Szeptycki. Pisma wybrane. Kraków: Znak.

Szeptycka, Z. z Fredrów, Zakrzewski, B. (oprac.) (1993). Mój syn metropolita Szeptycki. Młodość i powołanie ojca Romana Andrzeja Szeptyckiego zakonu św. Bazylego Wielkiego. B. Zakrzewski (red.). Wrocław: Towarzystwo Przyjaciół Polonistyki Wrocławskiej.

Szeptycki, A.R. (red.). (2011). Kościól, naród, państwo. Działalność i dziedzictwo Metropolity Andrzeja Szeptyckiego 1865-1944. Wrocław-Warszawa: Kolegium Europy Środkowo-Wschodniej im. Jana Nowaka-Jeziorańskiego i Fundacja Rodu Szeptyckich. 
Wawrzonek, M. (2010). Andrey Sheptytsky's “Christian Patriotism” in Light of Ukrainian Nationalism. W: J. Burbick, W. Glass (red.). Beyond Imagined Uniqueness: Nationalisms in Contemporary Perspectives. Newcastle upon Tyne: Cambridge Scholars Publishing.

Wnuk-Lipiński, E. (2004). Świat międzyepoki: globalizacja, demokracja, państwo narodowe. Kraków: Znak.

Voegelin, E. (1992). Nowa nauka polityki. Warszawa: Fundacja Aletheia.

Zarycki, T. (2009). Kapitał kulturowy - założenia i perspektywy zastosowań teorii Pierre'a Bourdieu. Psychologia Społeczna, 4, 1-2(10), 12-25.

Zięba, A.A. (red.). (1994). Metropolita Andrzej Szeptycki. Studia i materiały. Kraków: Polska Akademia Umiejętności.

Zięba, A.A. (1998). Dzieje legendy pośmiertnej metropolity Andrzeja Szeptyckiego. W: S. Stępień (red.). Polska - Ukraina: 1000 lat sąsiedztwa. Tom 4: Katolickie unie kościelne w Europie Środkowej i Wschodniej - Idea a rzeczywistość (287-310). Przemyśl: Południowo-Wschodni Instytut Naukowy.

Żochowski, P., Sadowski, R., Menkiszak, M. (2014, 3 września). Rosyjska interwencja zbrojna we wschodniej Ukrainie. OSW. Pobrane z: https://www.osw.waw.pl/pl/publikacje/ analizy/2014-09-03/rosyjska-interwencja-zbrojna-we-wschodniej-ukrainie.

\section{W języku ukraińskim}

Бусганг, Ю. (2009). Митрополит Шептицький. Ще один погляд на життя й діяльність. Львів: Друкарські куншти.

Верховна Рада України. (2014, 20 lutego). Стенограма пленарного засідання 20 лютого 2014 року. Засідання П’яте, Сесійний зал Верховної Ради України, 16.45 година, Веде засідання заступник Голови Верховної Ради України Р.В. Кошулинський. Верховна Рада України офіційний веб-портал. Pobrane z: http:// iportal.rada.gov.ua/meeting/stenogr/show/5164.html.

Верховна Рада України. (2014, 22 lutego). Стенограма пленарного засідання 22 лютого 2014 року. Засідання Сьоме, Сесійний зал Верховної Ради України, 10 година, Веде засідання заступник Голови Верховної Ради України Р.В. Кошулинський. Pobrane z: http://iportal.rada.gov.ua/meeting/stenogr/show/5168.html.

Верховна Рада України. (2014, 17 czerwca). Про відзначення 150-річчя з дня народження митрополита Української Греко-Католицької Церкви Андрея Шептицького. (Відомості Верховної Ради (ВВР), № 29, ст.953). Pobrane z: http://zakon2. rada.gov.ua/laws/show/1330-18.

Гугленко, Ю. (2015, 23 lipса). Про затвердження плану заходів з підготовки та відзначення в районі у 2015 роиі 150-річчя від дня народження митрополита Української греко-католицької церкви Андрея Шептицького. Знам’янка $\mathrm{nr} 213$. Pobrane z: http://zn.kr-admin.gov.ua/wp-content/uploads/2015/08/213_2015.pdf. Кабінет Міністрів України. (2015, 29 kwietnia). Про утворення Організаційного комітету та затвердження плану заходів з підготовки та відзначення у 2015 рочі 150-річчя від дня народження митрополита Української греко-католицької церкви Андрея Шептицького. Розпорядження, nr 585-p, Kijów. Pobrane z: https://zakon2.rada.gov.ua/laws/show/585-2015-p. 
Кузьменко, С. (2015, 10 lipса). Про затвердження плану заходів з підготовки та відзначення в області у 2015 році 150-річчя від дня народження митрополита Української греко-католицької иеркви Андрея Шептицького, nr 266-p. Pobrane z: http://kr-admin.gov.ua/Rozpor/Ua/ 2015/266.pdf.

Національний Меморіальний Комплекс Героїв Небесної Сотні. Музей Революції Гідності. (b.d.) Револющія Гідності. Pobrane z: http://www.maidanmuseum.org/ uk/storinka/revolyuciya-gidnosti.

Національний університет „Львівська Політехніка”. (2015, 4 listopada). В Університеті відбувся Міжнародний симпозіум до 150-річчя від дня народження Андрея Шептицького. Pobrane z: http://www.lp.edu.ua /news/2015/v-universytetividbuvsya-mizhnarodnyy-sympozium-do-150-richchya-vid-dnya-narodzhennya.

Прес-Служба Міністерства Культури. (2015, 5 таја). Відзначення 150-річчя від дня народження Андрея Шептицького має представити Митрополита як постать національного значення, - В'ячеслав Кириленко. Урядовий портал єдиний веб-портал органів виконавчої влади Украіни. Pobrane z: http://old.kmu. gov.ua/kmu/control/uk/publish/article?art_id=248138509\&cat_id=248817842.

Про доступ до архівів репресивних органів комуністичного тоталітарного режиму 1917-1991 років. (2015, 9 kwietnia). ЗАКОН УКРАЇНИ. Pobrane z: https:// zakon2.rada.gov.ua/laws/show/316-viii.

Про засудження комуністичного та націонал-сочіалістичного (нацистського) тоталітарних режимів в Україні та заборону пропаганди їхньої символіки. (2015, 9 kwietnia). ЗАКОН УКРАЇНИ. Pobrane z: https://zakon4.rada.gov.ua/laws/ show/317-viii.

Про правовий статус та вшанування пам'яті бориів за незалежність України у ХХ столітmі. (2015, 9 kwietnia). ЗАКОН УКРАЇНИ. Pobrane z: https://zakon2. rada.gov.ua/laws/show/314-viii.

Про увічнення перемоги над нацизмом у Другій світовій війні 1939-1945 років. (2015, 9 kwietnia).ЗАКОН УКРАЇНИ. Pobrane z: https://zakon4.rada.gov.ua/laws/ show/315-viii.

Управління освіти, науки, молоді та спорту Кіровоградської облдержадміністрації. (b.d.). Розпорядження голови Кіровоградської обласної державної адміністраuіï. Pobrane z: http://osvita.kr-admin.gov.ua/index.php/normativni-dokumenti/ rozporyadzhennya.

Християнський Портал Кіріос. (2015, 9 grudnia). На Кіровоградщині проходять заходи щзодо вщанування Митрополита Андрея Шептицького. Pobrane z: https://kyrios.org.ua/news/ugcc/19407-na-kirovogradschini-prohodjat-zahodischodo-vshanuvannja-mitropolita-andreja-sheptitskogo.html.

RISU. (2015, 3 listopada). Тиждень Митрополита Андрея в Києві та Львові. Pobrane z: https://risu.org.ua/ua/index/monitoring/religious_digest/61596/. 